\title{
CASE STUDIES ON STRENGTHENING OF CONCRETE AND MASONRY STRUCTURES
}

\author{
ESTUDIOS DE CASOS SOBRE EL REFORZAMIENTO \\ DE LAS ESTRUCTURAS DE HORMIGÓN Y MAMPOSTERÍA
}

\section{ANTONIO NANNI', ANDREA PROTA ${ }^{2}$}

1 University of Miami. Estados Unidos. nanni@miamiedu

2 Universita'di Napoli - Federico II. Italia. andrea.potra@unina.it

RESUMEN

Este artículo presenta una serie de estudios de casos relacionados con el fortalecimiento de estructuras de hormigón y mampostería dañadas por el terremoto del 6 de abril de $2009 M_{W} 6.3$ que azotó la ciudad italiana de L'Aquila y las localidades circundantes. Después de una breve reseña de los desafíos existentes en los edificios construidos antes de 1972, cuando el primer código de construcción que aborda la construcción sísmica se promulgó en Italia, el documento describe las intervenciones utilizando tecnologías que pueden ser consideradas innovadoras en que no se abordan en la mayoría de la actual Códigos de construcción en todo el mundo. Se describen los siguientes métodos de refuerzo: a) compuestos de polímero reforzado con fibra (FRP) en forma de disposición manual, laminados y espigas obtenidos; B) revestimiento de polímero reforzado con acero (SRP) y espigas; Y, c) la matriz de cemento reforzada con tejido (FRCM). El documento concluye con una descripción de cómo el despliegue de la innovación tiene lugar en los Estados Unidos. Este ejemplo tiene como objetivo identificar los desafíos a la innovación y un posible método para superarlos.

PALABRAS CLAVE: compuestos, hormigón, mampostería, daños sísmicos, fortalecimiento
This paper presents a number of case studies related to the strengthening of concrete and masonry structures damaged by the April 6, 2009, $M_{W} 6.3$ earthquake that struck the Italian city of L'Aquila and surrounding localities. After a brief overview of the existing challenges in buildings constructed prior to 1972 when the first building code addressing seismic construction was enacted in Italy, the paper describes interventions using technologies that can be considered innovative in that they are not addressed in the majority of the current building codes worldwide. The following strengthening methods are described: a) fiber-reinforced polymer (FRP) composites in the forms of manual lay-up, procured laminates and spikes; b) steel-reinforced polymer (SRP) lay-up and spikes; and, c) fabricreinforced cementitious matrix (FRCM). The paper concludes with a description of how the deployment of innovation for construction takes place in the United States. This example is intended to identify challenges to innovation and a possible method to overcome them.

KEYWORDS: composites, concrete, masonry, seismic damage, strengthening 
INTRODUCTION

Practically every nation in the world that is threatened by earthquakes suffers of the conditions exemplified by the case of Italy. In Italy, the building code specifically containing provisions for seismic design and construction was adopted in 1972. Thus, only buildings constructed since that date (less than 50 years ago) and assuming that they were code-compliant can be considered seismically resistant at least to a certain degree. As shown in figure 1 , this leaves over one third of the nonhistorical built stock or about one million buildings highly vulnerable to seismic events. It is evident that seismic rehabilitation and upgrade have become a national priority to ensure at least a minimum level of protection to its citizens.

CONSTRUCTION PERIOD

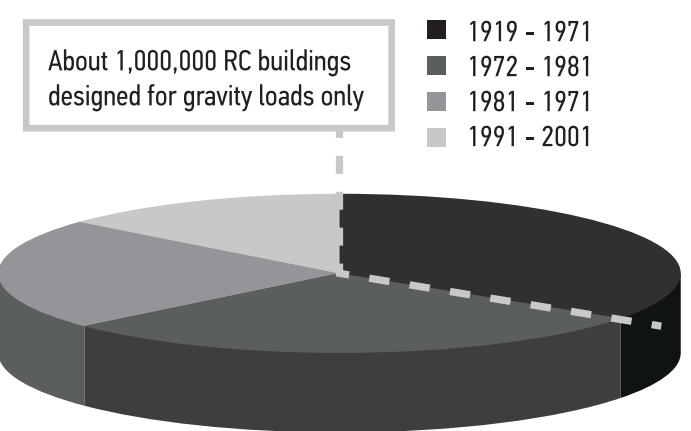

Figure 1. Magnitude of the challenge in Italy.

In the last decade, Italy has experienced two major earthquakes. The one that affected the city of L'Aquila and its surroundings on April 9, $2009\left(6.3 M_{W}\right)$ is by far the more relevant in terms of its toll on casualties and property damage. Apart from its dramatic social and economic consequences, this event was scientifically significant in that it clearly exposed all types of deficiencies affecting constructed facilities and became an opportunity for field-testing and deploying a host of rehabilitation and upgrading technologies. Accordingly, this paper presents case studies obtained from interventions such as: a) fiber-reinforced polymer (FRP) composites in the forms of manual lay-up, procured laminates and spikes; b) steel-reinforced polymer (SRP) lay-up and spikes; and, c) fabric reinforced cementitious matrix (FRCM). The design and construction of these interventions were conducted following the provision of the "Guide for the Design and Construction of Externally Bonded FRP Systems for Strengthening Existing Structures" (CNR DT 200 R1 - 2013) now in its second edition.
The paper concludes with a description of how the deployment of innovation for construction takes place in the United States. This example is intended to identify challenges to innovation and a possible method to overcome them that could be emulated in the Americas.

L'AQUILA EARTHQUAKE (EERI 2009)

On Monday April 6, 2009 at 3:32 AM local time, an $M_{W} 6.3$ earthquake with shallow focal depth $(10 \mathrm{~km})$ struck central Italy in the vicinity of L'Aquila, a city of about 73,000 people that is the capital of the Abruzzo region. The earthquake killed 305 people, injured 1,500, destroyed or damaged an estimated $10,000-15,000$ building, prompted the temporary evacuation of 70,00-80,000 residents, and left more than 24,000 homeless. This event was the strongest of a sequence that started a few months earlier and numbered 23 earthquakes of $M_{W}>4$ between 03/30/09 and 04/23/09, including an $\mathrm{Mw}$ 5.6 on $04 / 07$ and an $M_{W} 5.4$ on $04 / 09$.

In this region, the post-WWII residential buildings are of reinforced concrete construction, typically 2-4 stories tall, but reaching up to eight in some cases. Most are multifamily condominiums, and some have offices or retail stores at the ground floor. For building design purposes, L'Aquila was considered seismic after the 1915 Avezzano earthquake, and buildings have been designed according to seismic provisions ever since. The older RC buildings in the region use smooth reinforcing bars, unconventional lap splices, and in some cases, poorer quality construction materials. The frames are almost always designed with no consideration for the layout of masonry infill walls both in plan and elevation, as these are considered to be non-structural elements, and their exclusion is thought to lead to conservative design. The framing is filled in with one or two wythes of hollow clay or concrete blocks, and sometimes finished with wrap-around clay brick facades or stucco. Partitions are of thin hollow clay blocks.

The older unreinforced masonry (URM) dwellings in the historic centers (usually 2-3 stories) are built with stone and mortar walls; more recent URM structures show a mixed use of rubble-stone and clay bricks, and in some instances concrete blocks. In general, masonry buildings suffered a great amount of damage. 


\section{CONCRETE STRUCTURES}

When considering a reinforced concrete (RC) as the one schematically represented in figure 2 , one can recognize a number of critical elements that need be considered for the safe performance of a building when subject to lateral loads. This paper will provide a brief discussion of the five following examples of structural strengthening: external joints, shear in beams, flexure in joists, shear in columns and partitions. Interventions for deficiencies due to foundation problems (i.e., collapse or liquefaction) are out of the scope of this paper.

While the emphasis of this paper is on element strengthening, it is however important to stress that a successful rehabilitation and upgrade strategy has to consider the global behavior of the structure making sure that each element is treated according to a plan that includes consideration of design and/or execution errors, degradation of the materials, local stiffness, ductility and strength in a logical and hierarchical way.

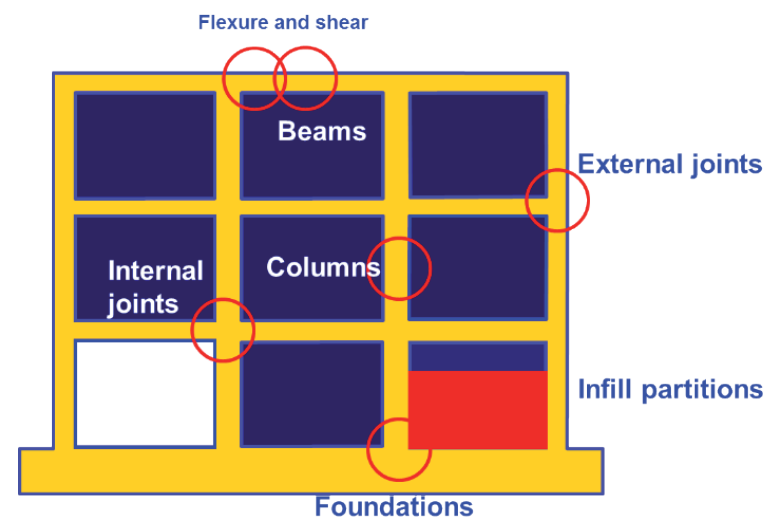

Figure 2. Critical elements in a building structure.

STRENGTHENING OF BEAM-COLUMN JOINTS

Beam-column joints are perhaps the most difficult element to correct in a framed RC structure. The greatest challenge is that of constructability and access due to the threedimensional geometry of the intersecting $\mathrm{Co}^{-}$ lumns and beams aggravated by the presence of the slab.

Many of the external joints of RC framed structures were gravely damaged by the action of the in-fill masonry partitions. In fact, during the oscillatory motion of the frame, a diagonal compression strut would form within the partition resulting on a force applied to the joint that was not accounted for in the design. In most instances joints failure was evidence by a pseudo-horizontal crack.
A possible rehabilitation technique adopted for the external joints of the school building shown in figure 3-a consisted of the following after exposure and repair of the concrete surfaces:

Shear strength increase of the joint panel. This was attained by first applying a diagonal sheet of SRP to resist the action of the partition followed by the superposition of a quadri-axial carbon FRP (CFRP) for shear capacity improvement.

1. Ductility increase of the column ends by confinement with continuous uniaxial CFRP wraps with fibers in the horizontal direction (see figure 3-b).

2. Shear strength increase of the beam ends obtained by the application of Ushaped wraps made of uniaxial CFRP sheets.
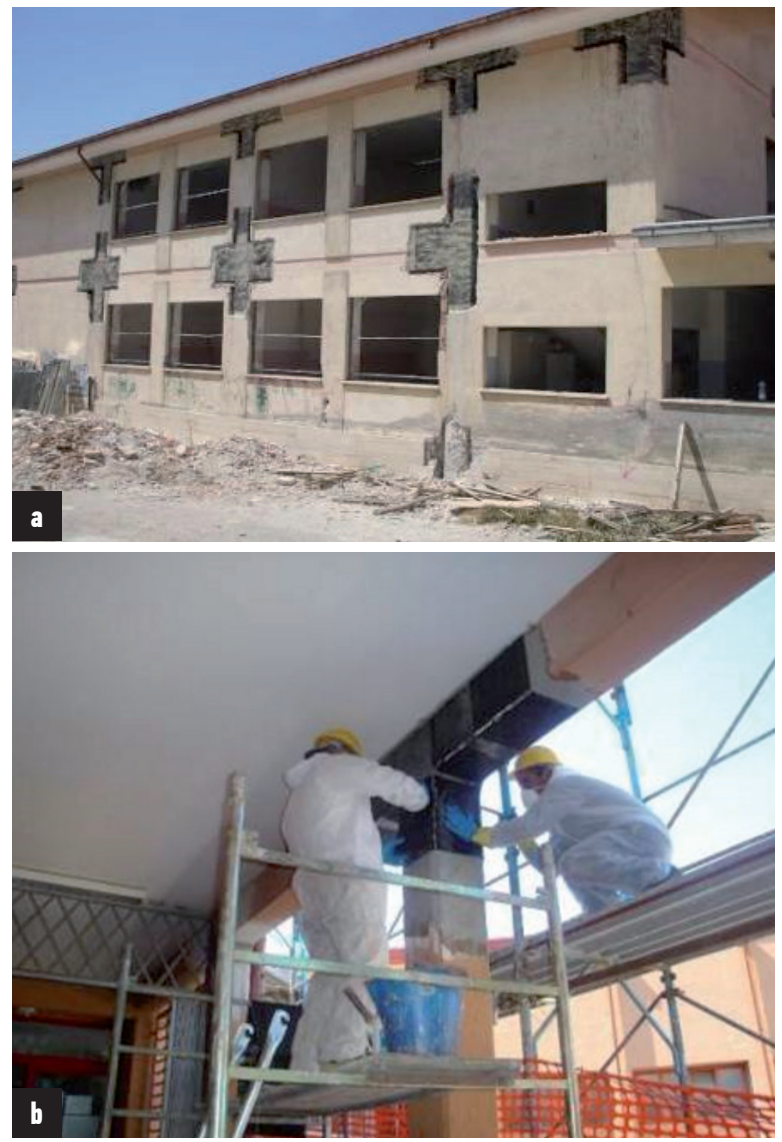

Figure 3. Prep work and strengthening of external joints.

SHEAR STRENGTHENING IN BEAMS

Shear strengthening of beams can be accomplished with CFRP U-wraps as shown in figure 4 where they act as external stirrups. Obviously a full-wrap would be more effective by allowing the full anchorage of the fiber sheet. This is however typically not possible due to the presence of the slab that makes a beam cross 
section either $\mathrm{T}$ or reverse-L shaped (interior or exterior beam).

The issue of U-wrap anchorage is of particularly challenging in the case of negative moment regions where the fiber sheet terminates at the face of the slab since this is the tension zone.

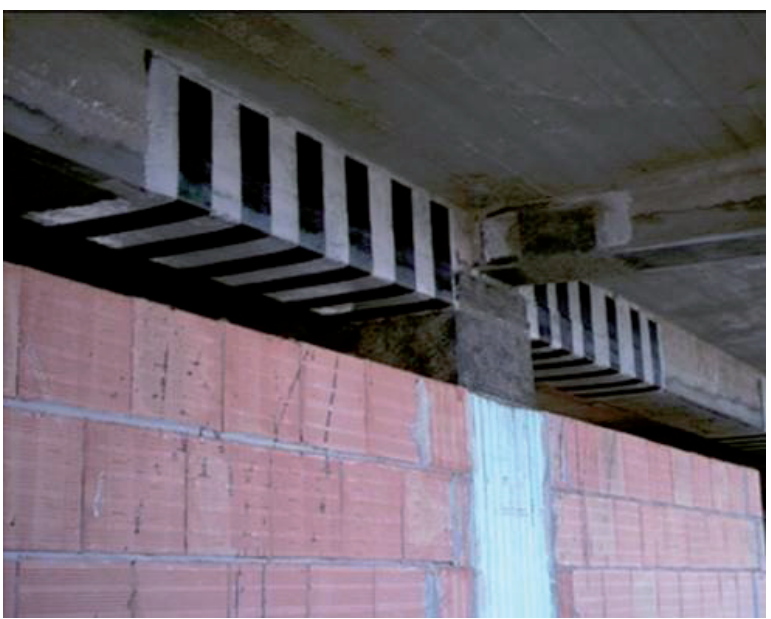

Figure 4. U-shaped CFRP wraps.

SHEAR STRENGTHENING IN COLUMNS

Column strengthening to address shear deficiency is primarily due to concrete poor quality (i.e., low compressive strength) and, even more commonly, improper tie spacing resulting from the application of outdated code provisions that only accounted for gravity loads. figure 5 shows the case of encasing the base of a square column using a CFRP full wrap with fibers in the direction perpendicular to the column axis.

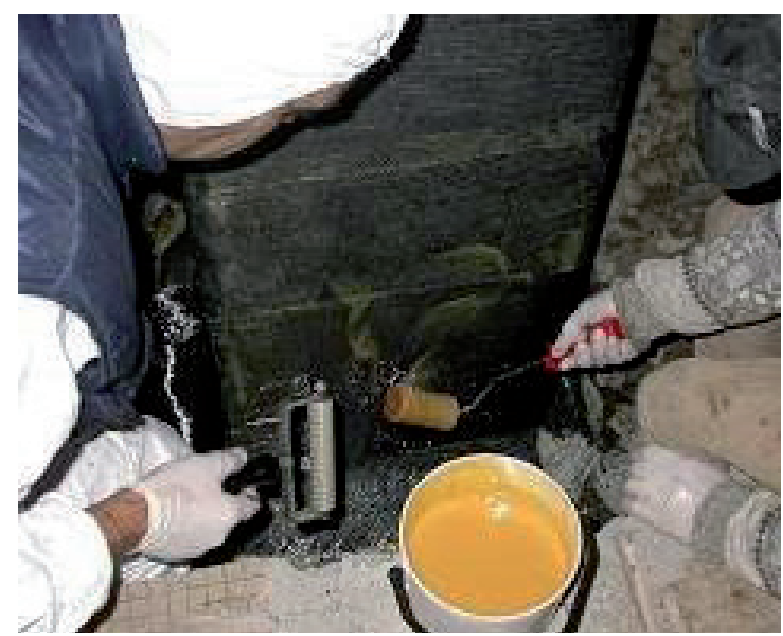

Figure 5. Strengthening of column by full CFRP wrap.

FLEXURE STRENGTHENING IN JOISTS

The most common method to fabricate floor slabs in RC framed buildings consists of hollow clay tiles connected integrally with RC joists (figure 6-a). In the case of cast-in-place joists, the tiles are laid first (becoming the equivalent of a mold) and supported by false work (i.e., shores). Steel reinforcing bars are inserted in the inner space between adjacent tiles and then concrete is cast. In most cases, a thin concrete topping is also cast with the joists to add stiffness and strength (and better load distribution) to the floor slab. As a variation, precast joists (RC or prestressed concrete (PC)) can be used to expedite construction and reduce the false work. Finally, panels using the same hybrid construction can be precast and deployed to the job site similarly to PC slabs more common in the Americas.

Figure 6-a shows the condition of the soffit of a floor slab with exposed reinforcing bars that are partially corroded. After steel treatment and concrete repair, pre-cured CFRP laminates (fabricated by pultrusion) are adhered to the bottom face to the joists (figure 6-b) to restore the flexural capacity of the system. This technique is similar to steel plate bonding also known as "béton plaqué."

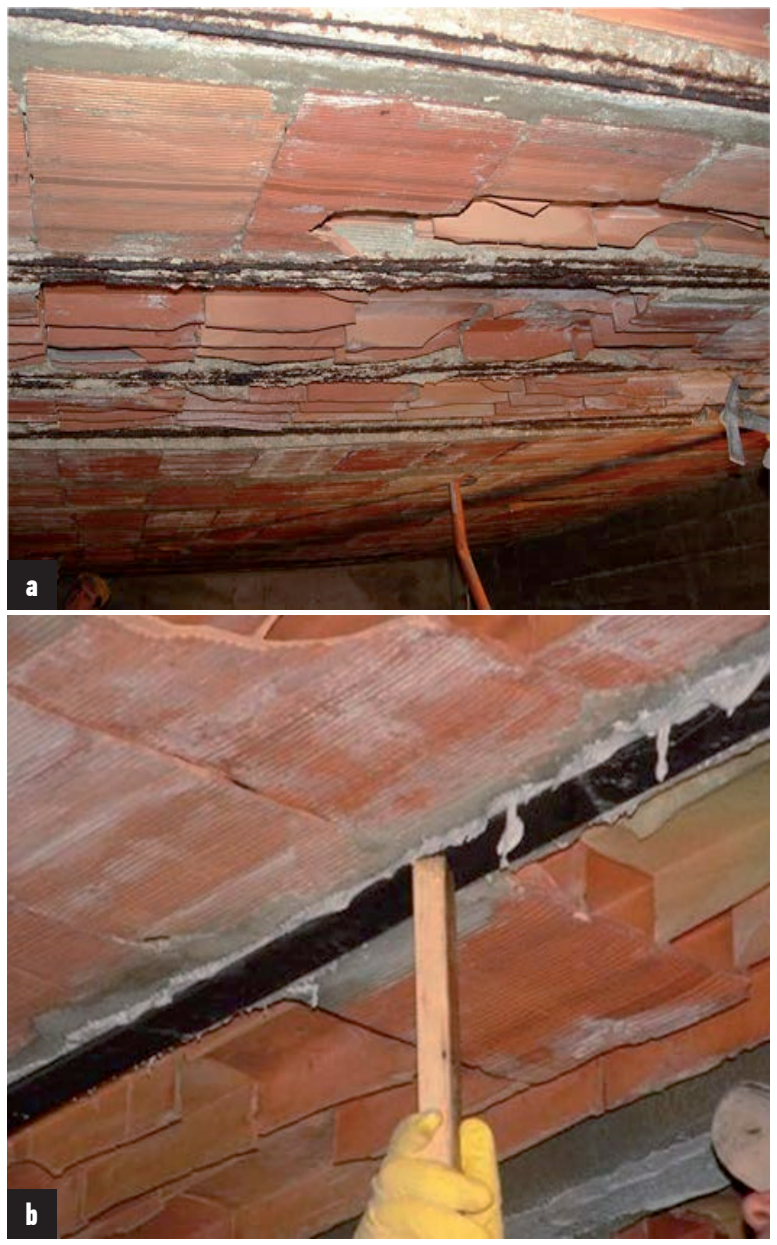

Figure 6. State of joist before repair and application of pre-cured CFRP laminate. 
STRENGTHENING OF PARTITIONS

The use of hollow clay infill panels is a common practice in buildings with reinforced concrete frames. One of the two possible failure modes of these non-structural elements is out-of-plane overturning that is a major concern in building facades due to the possible catastrophic consequences of falling debris.

The cause partition overturning is mainly due to the lack of proper connection to the RC frame (both vertically and horizontally). Thus, a possible repair method is the anchoring of the panel with glass FRCM and SRP spikes. First, the plaster covering the panel perimeter including portions of the concrete frame has to be removed. Second, passing hales are drilled in the partition at regular intervals along the perimeter for the installation of the spikes. Third, the cementitious grout and the alternating glass fabric reinforcement are applied in layers (see figure 7-a). Finally, the still spikes are installed in the pre-drilled holes, the wires fanned out and impregnated with resin (see figure 7-b) so that the proper continuity and two-face anchoring is established.
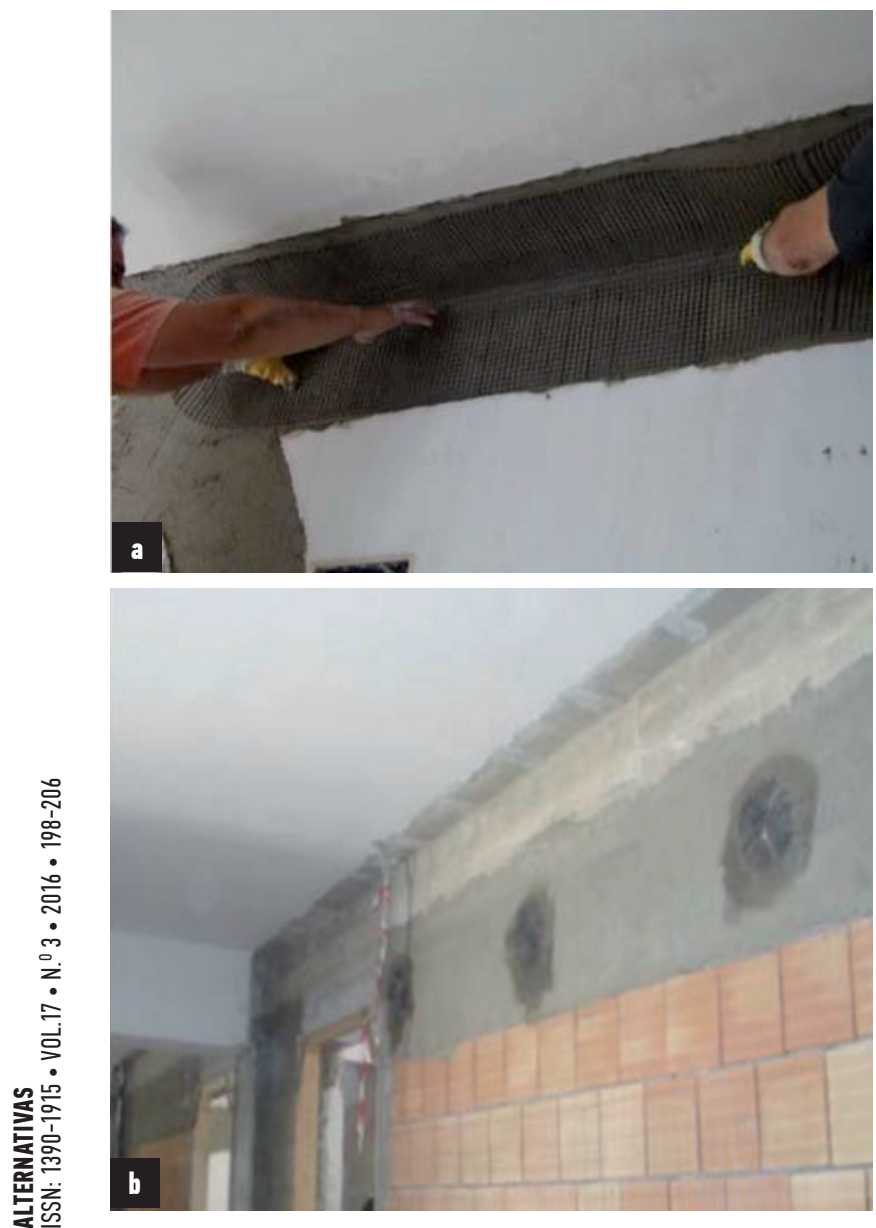

Figure 7. Partition anti-overturning repair with FRCM and SRP spikes.
MASONRY STRUCTURES

Unreinforced masonry buildings are particularly vulnerable to the effects of lateral loads due to seismic events. This is the result of the typically heavy mass and the lack of continuity among elements (e.g., walls and slabs). of particular concern are non-engineered structures made of low quality materials that have also undergone alterations due to the needs of modern living. This is the case of the building shown in figure 8 where the addition of a reinforced concrete stair on the second floor was responsible for significant damage and the collapse of the façade due to its stiffness and the consequent modification of the load path.

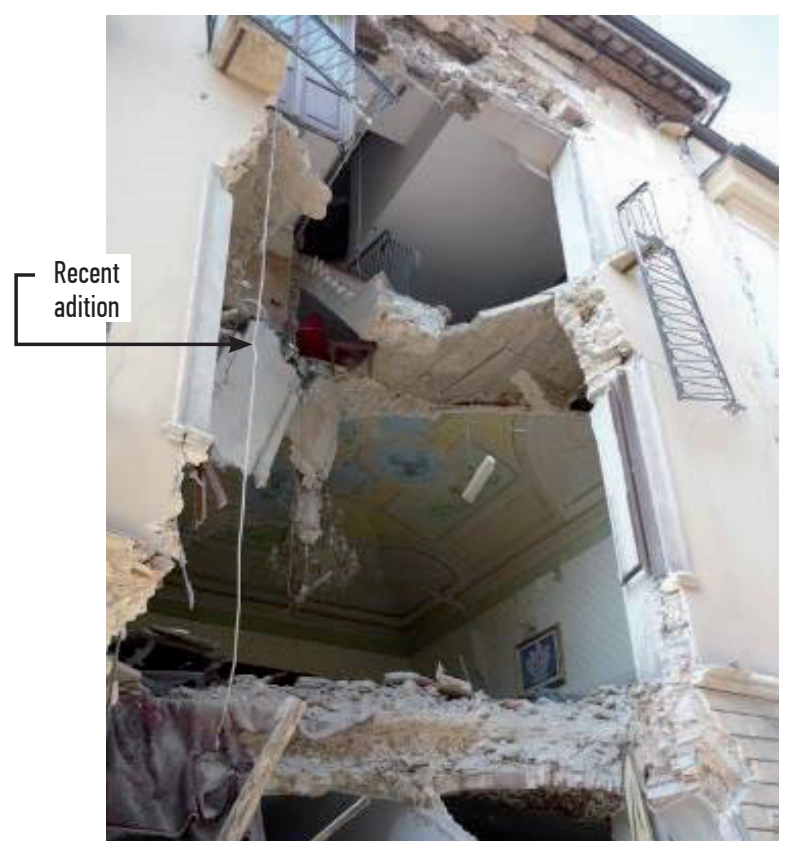

Figure 8. Damage resulting from insertion of concrete stair.

STRENGTHENING FOR OUT-OF-PLANE MECHANISMS

FRP retrofit measures can provide proper connection between walls as well as between walls and slabs preventing out-of-plane failures thus mobilizing in-plane strength of the walls under seismic actions. In the case of unreinforced masonry buildings, the optimal solution would be embracing the entire perimeter of the building with the selected FRP system.

The wrapping of masonry buildings at floor and roof locations can be achieved with FRP plies applied by wet lay-up (only rounding the corners of the building) anchored by FRP spikes as shown in figure 9-a and -b. The preparation of the substrate is of particular importance in order to provide a surface as flat as possible. $\mathrm{Re}^{-}$ entrant corners should be avoided. 

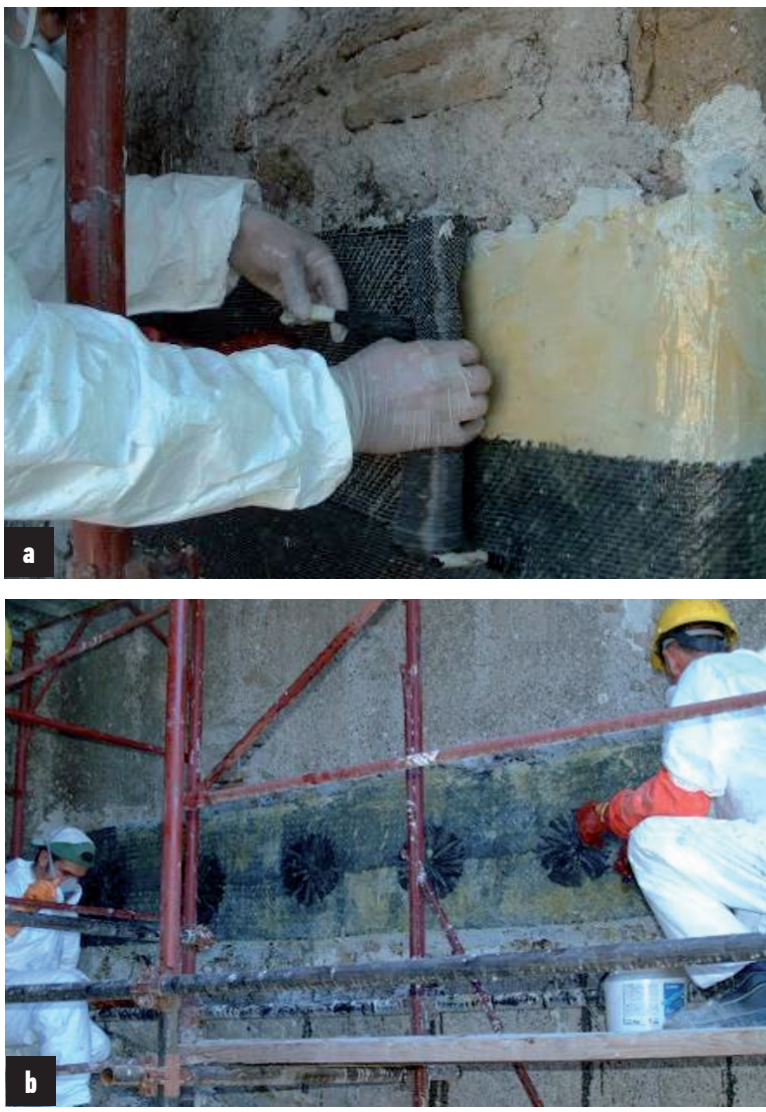

Figure 9. Wrapping with CFRP plies anchored with CFRP spikes.

STRENGTHENING FOR IN-PLANE MECHANISMS

Strengthening of masonry structures to enhance in-plane performance is as critical and needs to be addressed as part of a global intervention. figure 10-a shows the initial phase of surface preparation for the installation of a glass FRCM system. After removal of the plaster, the first layer of mortar is applied followed by the application of the glass fabric reinforcement. As noted in figure 10-b, the fabric is lapped to ensure stress transfer. Finally, as shown in figure $10^{-} \mathrm{c}$, passing holes are drilled for the insertion of Glass FRP spikes.

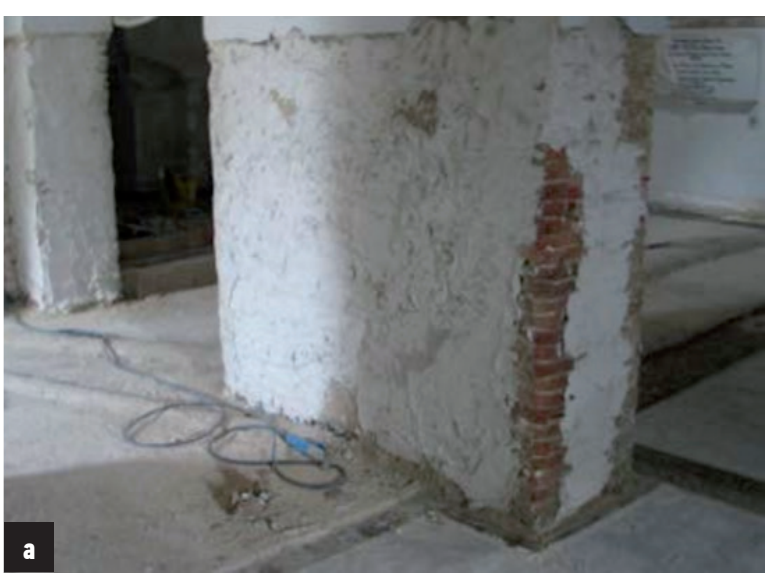

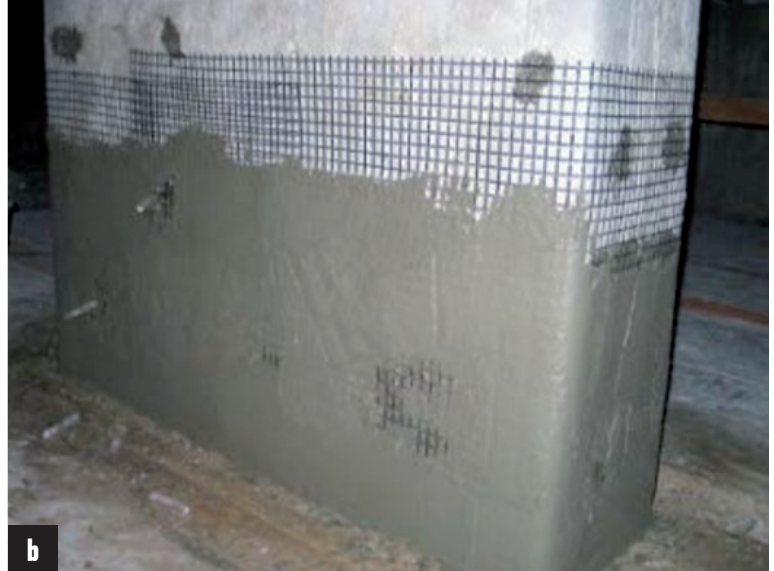

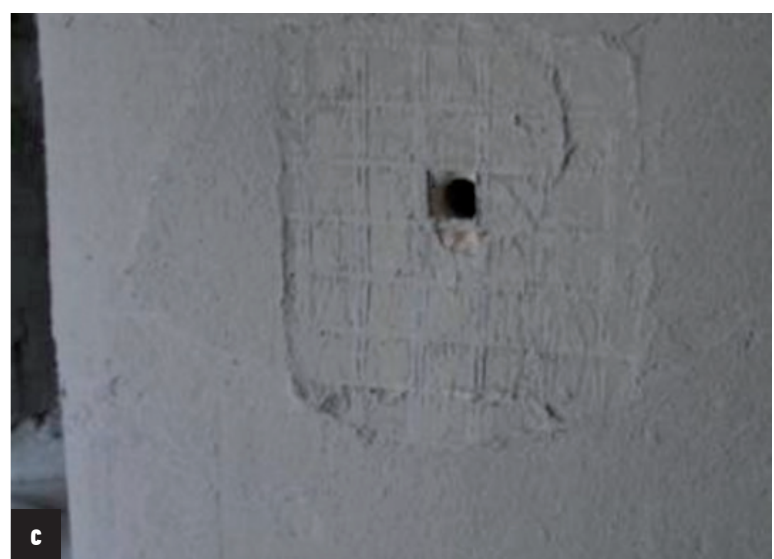

Figure 10. Application of mortar followed by carbon fabric and spikes.

DEPLOYMENT OF INNOVATION IN THE UNITED STATES BUILDING CODES AND USE OF ALTERNATIVE MATERIALS/METHODS

The practice of developing, approving, and enforcing building codes varies among countries. In some, building codes are developed by government agencies or quasi-governmental standards organizations and then enforced by the central government. Such codes are known as "national building codes." In other countries such as the United States, where the power of regulating construction and fire safety is vested in local authorities, a system of "model building codes" is used. The model codes become law in a jurisdiction when formally enacted by the appropriate governmental or private authority.

In the United States since 2015, the International Existing Building Code (IEBC 2015) includes all structural provisions related repair and rehabilitation of existing buildings. The purpose of the IEBC is to establish the $\mathrm{mi}^{-}$ nimum requirements to safeguard the public health and safety in existing buildings.

What happens if there is a new construction material or system that is an alternative to that 
covered in IEBC? Section 104.11 of IEBC states that:

"The provisions of this code are not intended to prevent the installation of any material or to prohibit any design or method of construction not specifically prescribed by this code, provided that any such alternative has been approved."

Subsection to Section 104.11 (Section 104.11.1) addresses the need for Research Reports. This Section states that:

"Supporting data, where necessary to assist in the approval of materials or assemblies not specifically provided for in this code, must consist of valid research reports from approved sources" that are accredited under ISO/IEC 17065.

Section 104.11.2 states that:

"Whenever there is insufficient evidence of compliance with the provisions of this code, or evidence that a material or method does not conform to the requirements of this code, or in order to substantiate claims for alternative materials or methods, the code officials have the authority to require tests as evidence of compliance to be made at no expense to the jurisdiction."

The existence of a set of protocols and provisions is therefore necessary in order to conduct the tests, the analysis of the results, the design, and the installation of the product on which to base the "Research Report." To this end, ICC Evaluation Service (ICC-ES) develops in partnership with the proposers of new technology specific documents called "Acceptance Criteria (AC)" for the purpose of issuing "Code Compliance Research (Evaluation) Reports" in accordance with Section 104.11. The AC typically outlines evaluation procedures for product sampling, testing and quality requirements to be fulfilled in order to obtain code-compliance verification. Once it is demonstrated that the product is manufactured under an approved quality control program, the research program outlined in the AC is conducted by an independent accredited laboratory certified under ISO/ IEC 17025. This international standard is the single most important standard, establishing the requirements for the competence of tes- ting and calibration laboratories around the world.

The outcomes of the research are then evaluated by ICC-ES and, assuming compliance, a research report is issued. The results of the data generated under an AC evaluation are finally published in a product-specific Evaluation $\mathrm{R}^{-}$ search Report. Code officials and other interested parties use a code compliance research report to help determine code compliance and enforce building regulations; manufacturers use this same report as evidence that their products comply with code requirements and warrant regulatory approval, design engineers can use to help their design.

\section{AC125}

IEBC does not include provisions for the structural capacity, reliability, durability, and serviceability of concrete and masonry elements strengthened with externally bonded FRPs, to address this shortcoming, ICC-ES established AC125 (titled: Acceptance Criteria for Concrete, and Reinforced and Unreinforced Masonry Strengthening, Using Externally Bonded Fiberreinforced Polymer). The purpose of $\mathrm{AC} 125$ is to provide the minimum requirements to qualify the use of FRP composite systems while meeting the main objectives of the building codes, including structural strength and serviceability, fire safety, and durability. AC125 is based on the available knowledge of FRP composites regarding performance, design procedures, and limitations at the time they are published.

In 2002, ACI Committee 440 published its first guide for the design and construction using externally bonded FRP composites (ACI 440.2R-02) for strengthening concrete structures. ACI 440.2R was the first comprehensive design guide that provided procedures and limitations as well as service and longterm performance requirements for FRP repair systems. In 2008, ACI 440 published the first revision to the FRP design guide that included significant changes to design requirements to address the influence of bond of externally bonded composites, strengthening of prestressed elements, and acceptable strengthening limits using FRP to guard against structural failure in case the externally bonded reinforcement was damaged due to fire or other causes (ACI 440.2R-08). Currently, there is no reference to the ACI $440.2 \mathrm{R}$ guide in IEBC, in part because the document is written in a nonmandatory format unsuitable for code enforcement. The use of FRP systems 
as a legitimate strengthening technology; however, is permitted by the recently developed ACI 562-13: Code Requirements for Evaluation, Repair, and Rehabilitation of Concrete Buildings and Commentary," which again cannot reference ACI 440.2R-08 for the same reason (i.e., non-mandatory language). It is envisioned that ACI 562 will eventually be referenced by IEBC.

To date, $\mathrm{AC} 125$ is used for code compliance verification of externally bonded FRP systems in repair of concrete and masonry buildings. FRP systems evaluated under $\mathrm{AC} 125$ are passive type systems (non-prestressed) applied by wet lay-up procedure. A manufacturer can decide to pursue evaluation for certain applications, be it concrete or masonry, columns or beams, as well as decide the purpose for strengthening, such as confinement, flexure or shear. AC125 requires full-scale structural testing and analysis of the test results to prove that the specified design methodologies and minimum performance requirements are verified.

AC125 also requires environmental and aging tests to prove that the long-term retention of relevant composite properties is 85 to 90 percent of the original properties, depending on the duration and type of exposure. To this end, the manufacturer would be mandated to create a qualification test plan that includes test matrix, test method, specimen configuration, and theoretical predictions to avoid unintended results and additional tests. For fire-recognition, both $\mathrm{AC} 125$ also provides fire-resistancerating test and evaluation provisions.

AC125 has two significant quality control provisions. The first concerns manufacturing of the component materials. It requires the quality control systems be documented to verify the materials are produced with the expectation that the performance remains as previously demonstrated by testing. As a means of verification, the quality system needs to be reviewed by an accredited inspection agency. Secondly, the certification body would require the inspection agency to inspect each manufacturing location regularly, no less than two times per year, to provide assurance that the materials are produced in accordance with the approved quality documentation.

CONCLUSIONS

Interventions performed in the Abruzzo Region, Italy, in the aftermath of the 2009 earthquake were discussed in this paper.
Both reinforced concrete and masonry structures addressed with and emphasis devoted to innovative solutions based on the use of advanced materials. Advanced materials allow increasing the seismic capacity of damaged or deficient structures by means of local interventions that:

a. for reinforced concrete structures are aimed at preventing brittle mechanisms (i.e., shear failure of beam-column joints, shear failure of short beams and columns, crushing of concrete and buckling of reinforcing bars at the column ends) and provide plastic hinges of columns with more rotational capacity in order to increase the displacement capacity of the structure. To this end, partitions should be protected in order to avoid their out-of-plane failure and to increase their in-plane integrity when the framed structure attains large displacements under earthquake;

b. for masonry structures are aimed at ensuring effective connections between walls and between walls and slabs in order to prevent local failures due to out-of-plane mechanisms; once this goal is obtained, advanced materials could also allow increasing the in-plane strength of masonry walls.

It is important to stress that local interventions can be performed following a careful engineering survey in order to assess design/ execution defects, level of degradation of materials or foundation problems. If one of these aspects is found to be relevant for the analyzed structures, the local interventions herein discussed can be effective only within a comprehensive plan of action that also considers interventions to address those additional problems.

Acceptance and deployment of innovation in construction remains a significant challenge and better protocols are needed to expedite a process that is presently rather lengthy and onerous. Existing provisions in the United States (Section 104.11 of IEBC) allow for the design and implementation of materials and technologies not covered by the model building codes. This mechanism is of great relevance to concrete repair, which among all segments of the construction industry is the one that needs creative and innovative solutions based on performance rather than prescriptive requirements. 


\section{ACKNOWLEDGEMENTS}

The authors gratefully acknowledges the $\mathrm{Na}^{-}$ tional Science Foundation (NSF) for the support provided to the Industry/University Center for Integration of Composites into Infrastructure (CICI) at the University of Miami under grant IIP-1439543. Any opinions, findings, and conclusions or recommendations expressed in this material are those of the authors and do not necessarily reflect the views of the NSF.

\section{REFERENCES}

AC125, "Acceptance Criteria for Concrete and Reinforced and Unreinforced Masonry Strengthening Using Externally Bonded Fiber-reinforced Polymer (FRP) composite systems," International Code Council-Evaluation Service, Brea, CA.

ACI Committee 440, "Guide for the Design and Construction of Externally Bonded FRP Systems for Strengthening Concrete Structures," ACI 440.2R-02 and ACI 440.2R-08, American Concrete Institute, Farmington Hills, MI, 2002 and 2008.

ACI Committee 562, "Code Requirements for Evaluation, Repair, and Rehabilitation of Concrete Buildings (ACI 562-13) and Commentary," ACI 562-13,
American Concrete Institute, Farmington Hills, MI, 2013.

CNR DT 200 R1 - 2013, "Guide for the Design and Construction of Externally Bonded FRP Systems for Strengthening Existing Structures," National Research Council, Rome, 10 Oct. 2013.

EERI, "The Mw 6.3 Abruzzo, Italy, Earthquake of April 6, 2009," Special Earthquake Report - June 2009.

International Code Council, "2015 International Existing Building Code (IEBC)," International Code Council, Country Club Hills, IL, 2014.

\section{BIOGRAPHIC SKETCHES}

Antonio Nanni, PhD, PE, FACI, FASCE, FIIFC is an Inaugural Senior Scholar, Professor and Chair, Department of Civil, Architectural \& Environmental Engineering, University of Miami. Dr. Nanni is a structural engineer interested in construction materials, their structural performance, and field application.

Andrea Prota, Ph.D., is a Professor of Structural Engineering at Department of Structures for Engineering and Architecture of the University of Naples - Federico II, Italy. 